\title{
Impact of parent rock and topography aspect on the distribution of soil trace metals in natural ecosystems
}

\author{
S. Rezapour · H. Golmohammad · H. Ramezanpour
}

Received: 5 January 2014/Revised: 8 June 2014/Accepted: 11 August 2014 / Published online: 26 August 2014

(C) Islamic Azad University (IAU) 2014

\begin{abstract}
The concentration and dynamic of soil trace metals in natural ecosystems, in particularly, is dependent on the lithology of parent rock as well as topography and geopedological processes. To ascertain more knowledge for this dependency, soils on three parent rocks involving peridotite, pegmatite, and dolerite in two contrasting topography aspects were investigated. The total values of $\mathrm{Fe}, \mathrm{Mn}, \mathrm{Zn}, \mathrm{Cu}$, and $\mathrm{Ni}$ were determined and compared for different soil pedons. The concentration of $\mathrm{Fe}, \mathrm{Mn}$, and $\mathrm{Ni}$ were highest in soils developed from peridotite (127, $1.8 \mathrm{~g} \mathrm{~kg}^{-1}$, and $218 \mathrm{mg} \mathrm{kg}^{-1}$, respectively), intermediate in soils derived from dolerite $\left(81,1.3 \mathrm{~g} \mathrm{~kg}^{-1}\right.$, and $166 \mathrm{mg} \mathrm{kg}^{-1}$, respectively), and least in soil developed from pegmatite $\left(50, \quad 0.23 \mathrm{~g} \mathrm{~kg}^{-1}\right.$, and $20 \mathrm{mg} \mathrm{kg}^{-1}$, respectively). The values of $\mathrm{Zn}$ and $\mathrm{Cu}$, originated from different parent rocks, were in order of dolerite $\left(78 \mathrm{mg} \mathrm{kg}^{-1}\right)>$ peridotite $\left(77 \mathrm{mg} \mathrm{kg}^{-1}\right)>$ pegmatite $(28$ $\left.\mathrm{mg} \mathrm{kg}^{-1}\right)$ and pegmatite $\left(121 \mathrm{mg} \mathrm{kg}^{-1}\right)>$ peridotite $\left(111 \mathrm{mg} \mathrm{kg}^{-1}\right)>$ dolerite $\left(28 \mathrm{mg} \mathrm{kg}^{-1}\right)$, respectively. For most of the studied pedons, profile metals distribution differed among the soils: The values of $\mathrm{Fe}, \mathrm{Cu}$, and $\mathrm{Ni}$ were enriched in the cambic horizons mainly as result of release, mobilization, and redistribution of the studied metals during geopedological processes, whereas those of $\mathrm{Zn}$ and $\mathrm{Mn}$ were concentrated in the surface horizons. Probably due to greater weathering rate of trace metal-bearing rocks on north-facing slope, the content of the trace metals along
\end{abstract}

S. Rezapour $(\bowtie)$

Soil Science Department, Urmia University, P.O. Box 165,

57134 Urmia, Islamic Republic of Iran

e-mail: S_Rezapour2000@yahoo.com

H. Golmohammad · H. Ramezanpour

Soil Science Department, Guilan University, Rasht, Islamic Republic of Iran with the geoaccumulation index $\left(I_{\text {geo }}\right)$ and the degree of soil contamination $\left(C_{\mathrm{d}}\right)$ were higher than on south-facing slope. Based on assessment of soil pollution indices, the soils were categorized as unpolluted $\left[I_{\text {geo }} \leq 0\right.$ (class 0$\left.)\right]$, unpolluted to moderately polluted levels $\left[0<I_{\text {geo }}<1\right.$ (class 1)], and very low $\left[C_{\mathrm{d}}<1.5\right.$ (class 0$\left.)\right]$ to low degree of contamination $\left[1.5<C_{\mathrm{d}}<2\right.$ (class 1 )].

Keywords Trace metal - Parent rock - Slope aspect . Pedon - Geopedological processes

\section{Introduction}

Soil contaminations by trace metals pose a serious threat to plants, animals, even human beings because of their bioaccumulation, non-biodegradable properties (Olgun and Atar 2011; Colaka et al. 2011). Naturally, the pattern of soil trace metals and in turn toxicity and deficiency of these metals are significantly influenced by variations in parent rock, environmental attributes, and pedoligical processes responsible for the formation of soils. Such issues should be understood better for the prediction and effective management of the trace metal behavior of soils. In uncontaminated soils, the overall content of these metals is associated with the geochemistry of parent rock (Brady and Weil 1999) from which soils derived because soil inherits from its a certain stock of elements that is then redistributed by pedological activities (Kabla and Szerszen 2002; Kabata-Pendias and Mukherjee 2007; Gupta et al. 2013). Bech et al. (1998) in the soils of Catalonia and Aussendorf et al. (2000) in the soils of NW Bavaria described that trace metals are a good tool to establish relationships between the soil and the parent rock. Overall, parent rocks containing high levels trace metals are mafic and ultramafic 
rather than siliceous rocks (Alloway 1995). In light of this, many igneous rocks such as olivine, augite, and hornblende are known as a rich source of some trace metals $(\mathrm{Mn}, \mathrm{Cu}$, $\mathrm{Zn}, \mathrm{Co}, \mathrm{Ni}$ ). In class of sedimentary rocks, shale has highest values of $\mathrm{Cr}, \mathrm{Mn}, \mathrm{Co}, \mathrm{Ni}, \mathrm{Cu}, \mathrm{Zn}, \mathrm{Cd}, \mathrm{Sn}, \mathrm{Hg}$, and $\mathrm{Pb}$ followed by limestone and sandstone (Nagajyoti et al. 2010). High levels of $\mathrm{Al}, \mathrm{Zn}, \mathrm{Mn}, \mathrm{Pb}, \mathrm{Ni}, \mathrm{Cu}$, and $\mathrm{Hg}$ have been also reported for volcanoes material (Seaward and Richardson 1990).

With time, the trace element status of soil will become different due to the influence of predominating pedogenic and geopedological processes (Kabata-Pendias and Mukherjee 2007). Although there is great diversity in the pedogenic processes contributing to the trend of trace metals, they can be generalized as (1) the physical and chemical processes of weathering (dissolution, hydration, hydrolysis, oxidation, reduction, and carbonatization) and (2) sorption, desorption, and the formation of various species of elements which are controlled by leaching, eluviation, podzolization, alkalization, aluminization, laterization, salization, and hydromorphic processes (Kabata-Pendias and Mukherjee 2007; Nael et al. 2009). Koons et al. (1980) and Rezapour and Samadi (2011) found that clay minerals, iron oxides, organic mater, and calcium carbonate, caused by weathering and pedological processes, are important significantly in the translocation and accumulation of trace metals. The data reported by Bulmer and Lavkulich (1994) and Paulo (Paulo et al. 2005) in British Columbia and Brazil, respectively, indicated that the concentration of $\mathrm{Cd}$, $\mathrm{Cu}, \mathrm{Ni}, \mathrm{Cr}$, and $\mathrm{Zn}$ were greater in $\mathrm{B}$ horizons compared to $\mathrm{A}$ and $\mathrm{C}$ horizons as result of extent of metals mobility into the soil profile.

The study area is a part of the Alborz mountain, a main mountain range in northern Iran, with least polluted compounds characterized by the diversity of parent rock and landform offering a diverse geopedological condition in which to study the effects of lithology and slope condition on the pattern of trace metals. The objectives of this work were the following: (1) to establish the regional background levels of $\mathrm{Fe}, \mathrm{Mn}, \mathrm{Zn}, \mathrm{Cu}$, and $\mathrm{Ni}$, (2) to investigate lithogenic and pedogenic processes influencing on the content and distribution of these metals, and (3) to assess some trace metals enrichment or depletion factors and the degree of pollution of the examined soils.

\section{Materials and methods}

Area description and soil sampling

This work was carried out in the Masouleh region, Guilan province, northern Iran (Fig. 1). The main parts of the study region are occupied by mountains and hills with elevation from 200 to $1,100 \mathrm{~m}$ above sea level. The average annual soil temperature and precipitation are $12{ }^{\circ} \mathrm{C}$ and $1,100 \mathrm{~mm}$, respectively. The soil moisture regime is udic and temperature regime is mesic. The natural vegetation is characterized by forest trees consisting mainly of Alnus subcordata, Zelkova carpinifolia, Carpinus betulus, and Mespilus germanica. Geologically, the area is characterized by Precambrian and Paleozoic metamorphic and mafic rocks as well as Cretaceous shale and limestone (Darvishzadeh 2002; Nael et al. 2009).

Six soil pedons from south- and north-facing slopes developed on different parent rocks consisting of peridotite (pedons 1 and 2), pegmatite, (pedons 3 and 4), and dolerite (pedons 5 and 6) were described and sampled. Soil samples were air-dried and passed through a 2-mm sieve (to remove rock fragments, roots, etc.) prior to laboratory analyses. Geological map of the region along with texture, structure, shape, color, etc., of each rock fragment was used to identify the parent rock in the field. The soils were classified (Soil Survey Staff 2010) as Typic Hapludolls (pedon 1), Typic Eutrudepts (pedon 2), Lithic Udorthents (pedons 3 and 4), and Dystric Eutrudepts (pedons 5 and 6).

\section{Analytical methods}

The analyses were made as follows: Particle size distribution was performed using the hydrometer method (Gee and Bauder 1986); soil $\mathrm{pH}$ in $0.1 \mathrm{M} \mathrm{KCl}$ using a 1:2.5 soil/ solution ratio; electrical conductivity in a $1: 5$ soil/water extract; organic matter by the Walkley-Black wet oxidation method (Nelson and Sommers 1982); cation exchange capacity (CEC) by the ammonium acetate method at $\mathrm{pH}$ of 8.2 (Chapman1965); and calcium carbonate equivalent (CCE) by acid neutralization (Nelson 1982).

Total heavy metals were extracted from the soil samples by aqua regia digestion method (Baker and Amacher 1982) using 3:1 (v/v) a mixture of $\mathrm{HCl}$ and $\mathrm{HNO}_{3}$. The soil extracts were analyzed for $\mathrm{Fe}, \mathrm{Mn}, \mathrm{Zn}, \mathrm{Cu}$, and $\mathrm{Ni}$ by atomic absorption spectrophotometer (AAS) using an airacetylene flame. The results for the trace metals were cited as mean values of each soil solum (A and B horizons) in the different soil pedons.

Assessment of soil contamination

Some approaches for trace metal soil contamination assessment have been proposed in the international literature in which the most important being: concentration factor (Rezapour and Samadi 2011); the geologic index (Müller 1969); the degree of contamination (Abrahim and Parker 2008); and pollution load index (PLI) (Cabrera et al. 1999). 
Fig. 1 Location of soil profile sites in the investigated region (Per peridotite, $\mathrm{Peg}$ pegmatite, Dol dolerite)

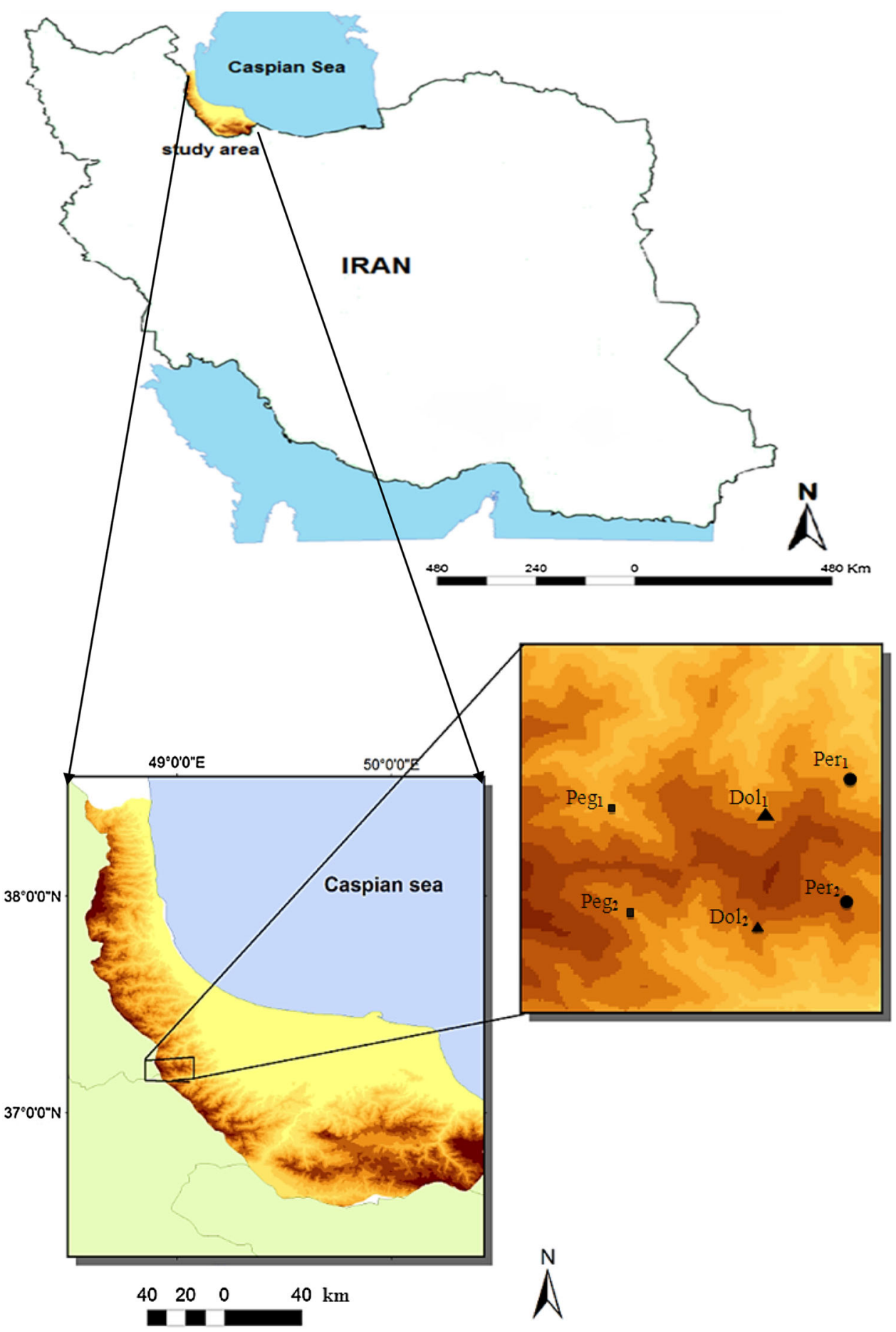

Concentration factor (CF) calculated as the concentration of each metal in the soil divided by concentration of soil reference metal.

The geologic index $\left(I_{\text {geo }}\right)$ calculated by the relation: $I_{\text {geo }}=\log _{2} C_{n} / 1.5 B_{n}$ where $C_{n}$ is the concentration of soil metal, $B_{n}$ is the background value of metal, and 1.5 is the correction factor of background contributed to lithogenic processes.
The degree of contamination $\left(C_{\mathrm{d}}\right)$ based on the sum total of the metal examined and calculated by following equation (Abrahim and Parker 2008):

$C_{\mathrm{d}}=\frac{\sum_{i=1}^{i=n} C_{\mathrm{F}}}{n}$

where $C_{\mathrm{F}}$ contamination factor, $n$ number of studied metals, and $i$ th the metals. The geologic index and the degree 
Table 1 The categorization of metal pollution in soils and sediments by $I_{\text {geo }}$ value (Müller 1969) and $C_{\mathrm{d}}$ value

\begin{tabular}{lll}
\hline$I_{\text {geo }}$ value & $I_{\text {geo }}$ class & Pollution intensity \\
\hline 0 & 0 & Uncontaminated \\
$0-1$ & 1 & Uncontaminated to moderately contaminated \\
$1-2$ & 2 & Moderately contaminated \\
$2-3$ & 3 & Moderately to strongly contaminated \\
$3-4$ & 4 & Strongly contaminated \\
$4-5$ & 5 & Strongly to extremely contaminated \\
$>5$ & 6 & Extremely contaminated \\
\hline$C_{\mathrm{d}}$ value & $C_{\mathrm{d}}$ class & Contamination degree \\
\hline$<1.5$ & 0 & Nil to very low degree of contamination \\
$1.5-2$ & 1 & Low degree of contamination \\
$2-4$ & 2 & Moderate degree of contamination \\
$4-8$ & 3 & High degree of contamination \\
$8-16$ & 4 & Very high degree of contamination \\
$16-32$ & 5 & Extremely high degree of contamination \\
$>32$ & 6 & Ultra high degree of contamination
\end{tabular}

of contamination proposed in some descriptive categories (Müller 1969; Abrahim and Parker 2008) as described in Table 1.

The PLI calculated as the $n$th root of the product of $n \mathrm{CF}$ (Kalavrouziotis et al. 2013) give by the following relation:

$$
\mathrm{PLI}=\sqrt[n]{\mathrm{CF} 1 \times \mathrm{CF} 2 \times \mathrm{CF} 3, \ldots, \mathrm{CF} n}
$$

where $\mathrm{CF}$ the concentration factor of metal, and numbers 1 , 2 , etc. correspond to the respective metal.

We considered the content of trace metals in the examined parent rocks as background (Table 2). Generally, the concentration of the trace metals in the examined parent rocks was in the follow sequences: $\mathrm{Fe}, \mathrm{Mn}, \mathrm{Zn}$, and $\mathrm{Ni}$ as peridotite $>$ dolerite $>$ pegmatite and $\mathrm{Cu}$ as pegmatite $>$ dolerite $>$ peridotite. Such pattern is in line with other reports (Kabata-Pendias and Mukherjee 2007). The mean of trace metal content for each profile used in the calculation of the examined indices (such enrichment of concentration factors) as

$M=\sum(D \times C) / \sum D$ where $D$ depth, $C$ trace metal value in each soil horizon.

The percentage of increase (enrichment) or decrease (depletion) of each element into soil was estimated using the following equation (Braun et al. 1993):

$$
\Delta \text { changes }=\mathrm{Cn}-\mathrm{Cb} / \mathrm{Cb} \times 100
$$

where $\mathrm{Cn}$ is the content of each element in the studied soil and $\mathrm{Cb}$ is the content of each element in the reference environment (background). In the equation, depletion is indicated by high $(-70$ to $-100 \%)$, average ( -40 to $-70 \%$ ), and low categories ( 0 to $-40 \%$ ) and enrichment is shown by low/average (40-100\%) and high categories $(>100 \%)$.

\section{Results and discussion}

Soil attributes

The results of the physicochemical analysis are illustrated in Table 3. For most of the investigated pedons, clay contents were generally lower in the surface horizons and some shallow $\mathrm{Bw}$ horizons than in the thicker B horizons which is likely due to the illuviation of clay particles in subsurface horizons or in situ weathering in B horizons. The silt contents show an inverse pattern compared to clay. Clay amounts ranges from as low as $11 \%$ in $\mathrm{C}$ horizon of pedon 3 and A horizon of pedon 7 as high as $48 \%$ in Bw1 and Bw2 horizons of pedon 2. Considerably, the soils on the north-facing slope contained a higher amount of clay than on the soils on south-facing slope in particular in the topsoil. Such pattern may be directly associated with weathering attributes, mainly temperature and moisture that can have improved clay amount during pedological processes on the northern slope.

The soil $\mathrm{pH}$ of the different horizons was slightly alkaline to acidic, ranging from as low as 4.78 in $\mathrm{Bw}$ horizon of pedon 5 to as high as 7.4 in $\mathrm{C}$ horizon of pedon 2 (Table 3). Typically, the $\mathrm{pH}$ values show an increasing trend with depth, probably due to the leaching of basic compounds and calcium carbonates. The lowest values of $\mathrm{pH}$ occur in soils from pegmatite which is rich in $\mathrm{SiO}_{2}$ with felsic properties, varying between 4.78 and 5.47. In

Table 2 The concentration of selected trace metals in the examined parent rocks

\begin{tabular}{lllllr}
\hline Parent rock & $\mathrm{Fe}\left(\mathrm{g} \mathrm{kg}^{-1}\right)$ & $\mathrm{Mn}\left(\mathrm{g} \mathrm{kg}^{-1}\right)$ & $\mathrm{Zn}\left(\mathrm{mg} \mathrm{kg}^{-1}\right)$ & $\mathrm{Cu}_{\left(\mathrm{mg} \mathrm{kg}^{-1}\right)}$ & $\mathrm{Ni}\left(\mathrm{mg} \mathrm{kg}^{-1}\right)$ \\
\hline Peridotite (ultramafic) & 99.0 & 1.3 & 79.8 & 35.5 & 177 \\
Pegmatite (felsic) & 12.2 & 0.22 & 55.0 & 62.5 & 14 \\
Dolerite (mafic) & 94.5 & 1.005 & 78.8 & 56.0 & 105 \\
\hline
\end{tabular}


Table 3 Selected physicochemical properties for the investigated soils

\begin{tabular}{|c|c|c|c|c|c|c|c|c|c|}
\hline \multirow[t]{2}{*}{ Pedon } & \multirow[t]{2}{*}{ Horizon } & \multirow[t]{2}{*}{ Depth $(\mathrm{cm})$} & \multicolumn{3}{|c|}{ Particle size distribution $(\%)$} & \multirow[t]{2}{*}{$\mathrm{pH}$} & \multirow{2}{*}{$\begin{array}{l}\mathrm{SOM} \\
\left(\mathrm{g} \mathrm{kg}^{-1)}\right.\end{array}$} & \multirow{2}{*}{$\begin{array}{l}\mathrm{CaCO}_{3} \\
\left(\mathrm{~g} \mathrm{~kg}^{-1}\right)\end{array}$} & \multirow{2}{*}{$\begin{array}{l}\mathrm{CEC} \\
\left(\mathrm{cmol}_{\mathrm{c}} \mathrm{kg}^{-1}\right)\end{array}$} \\
\hline & & & Sand & Silt & Clay & & & & \\
\hline \multicolumn{10}{|c|}{ Parent rock: peridotite (north-facing slope), classification: Typic Hapludolls } \\
\hline \multirow[t]{5}{*}{1} & A & $0-13$ & 35.10 & 29.84 & 35.04 & 6.65 & 94.1 & 2.0 & 50.83 \\
\hline & $\mathrm{AB}$ & $13-35$ & 36.35 & 28.21 & 35.42 & 6.71 & 46.4 & 1.8 & 43.14 \\
\hline & Bw1 & $35-70$ & 27.03 & 24.38 & 48.58 & 6.86 & 19.5 & 10.6 & 49.11 \\
\hline & Bw2 & $70-100$ & 29.21 & 22.43 & 48.35 & 6.95 & 13.4 & 11.0 & 54.29 \\
\hline & $\mathrm{BC}$ & $100-140$ & 53.46 & 17.30 & 29.23 & 7.4 & 0.90 & 12.0 & 44.69 \\
\hline \multicolumn{10}{|c|}{ Parent rock: peridotite (south-facing slope), classification: Typic Eutrudepts } \\
\hline \multirow[t]{5}{*}{2} & A & $0-9$ & 58.46 & 18.08 & 23.44 & 6.63 & 66.7 & 12.1 & 34.85 \\
\hline & BA & $9-40$ & 51.65 & 21.89 & 26.45 & 6.77 & 17.7 & 12.4 & 29.40 \\
\hline & Bw1 & $80-40$ & 51.75 & 22.48 & 25.76 & 6.78 & 10.1 & 13.8 & 31.29 \\
\hline & Bw2 & $80-110$ & 51.28 & 19.59 & 29.12 & 6.99 & 6.7 & 15.2 & 35.48 \\
\hline & $\mathrm{CB}$ & $110-130$ & 65.95 & 13.45 & 20.59 & 6.97 & 1.3 & 17.0 & 32.36 \\
\hline \multicolumn{10}{|c|}{ Parent rock: pegmatite (north-facing slope), classification: Lithic Udorthents } \\
\hline \multirow[t]{3}{*}{3} & A & $0-12$ & 42.25 & 41.24 & 16.49 & 5.41 & 90.9 & 1.0 & 28.1 \\
\hline & Bw & $12-27$ & 47.28 & 36.69 & 16.02 & 4.98 & 33.6 & nd & 24.16 \\
\hline & $\mathrm{C}$ & $27-50$ & 49.42 & 37.52 & 13.04 & 5.34 & 13.4 & nd & 11.76 \\
\hline \multicolumn{10}{|c|}{ Parent rock: pegmatite (south-facing slope), classification: Lithic Udorthents } \\
\hline \multirow[t]{3}{*}{4} & A & $0-12$ & 44.59 & 39.26 & 16.13 & 5.44 & 53.7 & 1.0 & 26.42 \\
\hline & $\mathrm{Bw}$ & $12-22$ & 46.82 & 37.45 & 15.71 & 4.78 & 40.3 & nd & 16.37 \\
\hline & $\mathrm{C}$ & $27-40$ & 50.51 & 03.36 & 13.44 & 4.96 & 18.9 & nd & 11.46 \\
\hline \multicolumn{10}{|c|}{ Parent rock: dolerite (north-facing slope), classification: Dystric Eutrudepts } \\
\hline \multirow[t]{4}{*}{5} & A & $0-10$ & 76.9 & 12.0 & 11.1 & 6.8 & 36 & 17.1 & 16.4 \\
\hline & Bw1 & $10-45$ & 77.5 & 11.3 & 11.2 & 7.1 & 8.0 & 10.4 & 13.5 \\
\hline & Bw2 & $45-60$ & 76.6 & 10.8 & 12.6 & 7.2 & 3.0 & 14.2 & 15.7 \\
\hline & $\mathrm{CB}$ & $60-80$ & 76.7 & 9.8 & 13.5 & 7.3 & 1.1 & 5.1 & 18.3 \\
\hline \multicolumn{10}{|c|}{ Parent rock: dolerite (South-facing slope), classification: Dystric Eutrudepts } \\
\hline \multirow[t]{3}{*}{6} & A & $0-10$ & 75.3 & 15.3 & 9.4 & 6.9 & 28 & 14.2 & 14.1 \\
\hline & Bw & $10-60$ & 75 & 14 & 11 & 7.3 & 6.1 & 12.2 & 13.1 \\
\hline & $\mathrm{C}$ & $60-80$ & 84 & 6.5 & 9.5 & 7.4 & nd & 4.2 & 12.8 \\
\hline
\end{tabular}

SOM soil organic matter, $C E C$ cation exchange capacity, $n d$ not detected

contrast, the highest amounts of $\mathrm{pH}$ observe in soils developed from peridotite which is rich in $\mathrm{Fe}-\mathrm{Mg}$ with ultramafic properties.

The specific environmental condition such as the relatively high rainfall, dense vegetation, high soil $\mathrm{CO}_{2}$ concentration, and well-drained conditions facilitated calcium carbonates removal or depletion from the upper horizons and translocation and precipitation to lower horizons (Khormali et al. 2012). Electrical conductivity was lower than $1 \mathrm{dS} \mathrm{m}^{-1}$ in all the examined pedons (the data not shown).

The amount of organic matter in all pedons is highest in the surface horizons (ranging from 36 to $96 \mathrm{~g} \mathrm{~kg}^{-1}$ ) and decrease abruptly with depth (Table 3). The soils on the north-facing slope contained a greater amount of organic matter than on the soil on south-facing slope. This trend suggests to a different sensitivity of the organic matter to mineralization of humification processes between the north- and south-facing slopes (Sidari et al. 2008). The CEC values are low to high, varying from 12 to $54 \mathrm{cmol}_{\mathrm{c}} \mathrm{kg}^{-1}$. The highest CEC content is observed in the horizons of $\mathrm{A}$ and $\mathrm{Bw} 2$ of pedon 2, where the greatest clay content and organic matter are occurred.

The distribution of trace metals

The distribution of selected trace metals showed a considerable range of variations into soil pedons (Table 4). In 
Table 4 Mean \pm standard deviation values of selected trace metal on the north- $(\mathrm{N})$ and south-facing $(\mathrm{S})$ slope aspects in soils developed on the different parent rocks

\begin{tabular}{|c|c|c|c|c|c|c|}
\hline \multirow[t]{2}{*}{ Trace metal } & \multicolumn{2}{|l|}{ Mean \pm SD } & \multicolumn{2}{|c|}{ REF or RDF } & \multicolumn{2}{|c|}{$\Delta$ changes $(\%)$} \\
\hline & $\mathrm{N}$ & $\mathrm{S}$ & $\mathrm{N}$ & $\mathrm{S}$ & $\mathrm{N}$ & $\mathrm{S}$ \\
\hline \multicolumn{7}{|l|}{ Peridotite } \\
\hline $\mathrm{Fe}\left(\mathrm{g} \mathrm{kg}^{-1}\right)$ & $127.24 \pm 20.1$ & $127.47 \pm 8.01$ & 1.3 & 1.3 & $28.5(\mathrm{~L})$ & $28.76(\mathrm{~L})$ \\
\hline $\operatorname{Mn}\left(\mathrm{g} \mathrm{kg}^{-1}\right)$ & $2.0 \pm 0.4$ & $1.5 \pm 0.17$ & 1.5 & 1.2 & $53.85(\mathrm{~A})$ & $15.38(\mathrm{~L})$ \\
\hline $\mathrm{Zn}\left(\mathrm{mg} \mathrm{kg}^{-1}\right)$ & $71.9 \pm 10.6$ & $82.23 \pm 33.47$ & 0.9 & 1.03 & $-10.0(\mathrm{~L})$ & $3.05(\mathrm{~L})$ \\
\hline $\mathrm{Cu}\left(\mathrm{mg} \mathrm{kg}^{-1}\right)$ & $99.5 \pm 11.4$ & $122.33 \pm 11.1$ & 2.8 & 3.5 & $181(\mathrm{H})$ & $247(\mathrm{H})$ \\
\hline $\mathrm{Ni}\left(\mathrm{mg} \mathrm{kg}^{-1}\right)$ & $290 \pm 193.5$ & $146.2 \pm 13.7$ & 1.6 & 0.83 & $63.8(\mathrm{~A})$ & $-17.4(\mathrm{~L})$ \\
\hline \multicolumn{7}{|l|}{ Pegmatite } \\
\hline $\mathrm{Fe}\left(\mathrm{g} \mathrm{kg}^{-1}\right)$ & $50.38 \pm 1.46$ & $49.26 \pm 3.98$ & 4.1 & 4.03 & $313(\mathrm{H})$ & $303(\mathrm{H})$ \\
\hline $\operatorname{Mn}\left(\mathrm{g} \mathrm{kg}^{-1}\right)$ & $0.24 \pm 0.08$ & $0.22 \pm 0.04$ & 1.1 & 1.0 & 18.9 (L) & $8.7(\mathrm{~L})$ \\
\hline $\mathrm{Zn}\left(\mathrm{mg} \mathrm{kg}^{-1}\right)$ & $28.5 \pm 9.5$ & $27.09 \pm 12.07$ & 0.52 & 0.49 & $-48.2(\mathrm{~A})$ & $-50.7(\mathrm{~A})$ \\
\hline $\mathrm{Cu}\left(\mathrm{mg} \mathrm{kg}^{-1}\right)$ & $134.4 \pm 13.4$ & $107.3 \pm 11.8$ & 2.1 & 1.7 & $114.9(\mathrm{H}$ & $71.6(\mathrm{~A})$ \\
\hline $\mathrm{Ni}\left(\mathrm{mg} \mathrm{kg}^{-1}\right)$ & $17.5 \pm 12.0$ & $23.2 \pm 7.6$ & 1.3 & 1.7 & $25.0(\mathrm{~L})$ & $65.6(\mathrm{~A})$ \\
\hline \multicolumn{7}{|l|}{ Dolerite } \\
\hline $\mathrm{Fe}\left(\mathrm{g} \mathrm{kg}^{-1}\right)$ & $98.74 \pm 6.96$ & $62.7 \pm 5.31$ & 1.0 & 0.66 & $4.5(\mathrm{~L})$ & $-33.65(\mathrm{~L})$ \\
\hline $\operatorname{Mn}\left(\mathrm{g} \mathrm{kg}^{-1}\right)$ & $1.23 \pm 0.19$ & $1.34 \pm 0.03$ & 1.23 & 1.32 & $22.22(\mathrm{~L})$ & $32.2(\mathrm{~L})$ \\
\hline $\mathrm{Zn}\left(\mathrm{mg} \mathrm{kg}^{-1}\right)$ & $99.99 \pm 6.44$ & $55.48 \pm 3.5$ & 1.3 & 0.70 & $27.1(\mathrm{~L})$ & $-29.5(\mathrm{~L})$ \\
\hline $\mathrm{Cu}\left(\mathrm{mg} \mathrm{kg}^{-1}\right)$ & $42.61 \pm 11.3$ & $13.18 \pm 1.34$ & 0.76 & 0.24 & -23.9 (L) & $-76.5(\mathrm{~A})$ \\
\hline $\mathrm{Ni}\left(\mathrm{mg} \mathrm{kg}^{-1}\right)$ & $127.14 \pm 18.8$ & $206.44 \pm 31.8$ & 1.2 & 2.0 & $21.1(\mathrm{~L})$ & $96.6(\mathrm{~A})$ \\
\hline
\end{tabular}

$R E F$ relative enrichment factor, $R D F$ relative depletion factor

Categorizations for change percentage, $L$ low, $A$ average, $H$ high

this context, the metal levels ranged as follow: Fe from 45.22 to $156.46 \mathrm{~g} \mathrm{~kg}^{-1}$, Mn from 0.126 to $2.49 \mathrm{~g} \mathrm{~kg}^{-1}, \mathrm{Zn}$ from 12.4 to $132.8 \mathrm{mg} \mathrm{kg}^{-1}$, $\mathrm{Cu}$ from 12.1 to 148 . $8 \mathrm{mg} \mathrm{kg}^{-1}$, and $\mathrm{Ni}$ from 5.5 to $5848 \mathrm{mg} \mathrm{kg}^{-1}$. Such pattern is not surprising, especially in view point of the fact that ultramafic (such as peridotite) and mafic (such as dolerite) rocks are richer in $\mathrm{Fe}, \mathrm{Mn}$, and $\mathrm{Ni}$ than other rocks (Kabata-Pendias and Mukherjee 2007). In both north-and south-facing slopes, soils developed on peridotite showed the highest concentration of $\mathrm{Fe}, \mathrm{Mn}$ and $\mathrm{Ni}$, followed by the soils on dolerite, and lowest in the soils of pegmatite. The values of $\mathrm{Zn}$ and $\mathrm{Cu}$ were in the order of pedons on peridotite $>$ dolerite $>$ pegmatite and pedons on peridotite $>$ pegmatite $>$ dolerite, respectively, in the southern slope (Table 4). For most of the pedons, soils developed on the southern slope show generally less enrichment than those on the northern slope (Table 4). For example, the mean concentration of $\mathrm{Cu}$ in soils derived from pegmatite on the southern slope show a rise $72 \%$ (REF of 1.7), while the content of $\mathrm{Cu}$ on the northern slope from the same soil and rock show a rise $115 \%$ (REF of 2.1) comparing to the reference. These trends may be due to the different surface erosion rates and pedogenic processes as well as the duration and kinetics of chemical weathering induced by aspect, considering that the important role of slope aspect in generating different microclimate condition (such as soil temperature and moisture content and native vegetation) at the catchments scale by controlling the degree of solar radiation received by surface (Ma et al. 2011).

In soils derived from peridotite (pedons 1 and 2), Fe, $\mathrm{Mn}$, and $\mathrm{Cu}$ are enriched in the cambic horizons mainly in the northern slopes (Table 5). The enrichment was least for $\mathrm{Cu}$, intermediate for $\mathrm{Mn}$, and strong for Fe. This pattern may be interpreted to release, mobilization, and redistribution these elements during geopedological processes. Consistent with this, $\mathrm{Fe}, \mathrm{Mn}$, and $\mathrm{Cu}$ were most likely first released to solution during chemical weathering. The metals then sorbed by fine clay particles and subsequently accumulated through illuviation in B horizon (Nael et al. 2009; Ma et al. 2011; Acosta et al. 2011). In pedons 3 and 4 , developed on pegmatite, $\mathrm{Mn}$ and $\mathrm{Zn}$ were enriched in the surface horizons with higher enrichment for the northern 
Table 5 Vertical distribution of selected trace metals in soils developed on three types of parent rocks

\begin{tabular}{|c|c|c|c|c|c|c|c|}
\hline Pedon & Horizon & Depth $(\mathrm{cm})$ & $\mathrm{Fe}\left(\mathrm{g} \mathrm{kg}^{-1}\right)$ & $\operatorname{Mn}\left(\mathrm{g} \mathrm{kg}^{-1}\right)$ & $\mathrm{Zn}\left(\mathrm{mg} \mathrm{kg}^{-1}\right)$ & $\mathrm{Cu}\left(\mathrm{mg} \mathrm{kg}^{-1}\right)$ & $\overline{\mathrm{Ni}\left(\mathrm{mg} \mathrm{kg}^{-1}\right)}$ \\
\hline \multicolumn{8}{|c|}{ Parent rock: peridotite (north-facing slope) } \\
\hline \multirow[t]{5}{*}{1} & A & $0-13$ & 100.2 & 1.88 & 75.5 & 76.5 & 119.0 \\
\hline & $\mathrm{AB}$ & $13-35$ & 108.0 & 2.06 & 78.3 & 111.5 & 124.5 \\
\hline & Bw1 & $35-70$ & 117.8 & 2.42 & 74.5 & 101.0 & 138.5 \\
\hline & Bw2 & $70-100$ & 136.8 & 2.49 & 76.0 & 102.5 & 251.0 \\
\hline & $\mathrm{BC}$ & $100-140$ & 156.5 & 1.62 & 48.5 & 96.5 & 584.0 \\
\hline \multicolumn{8}{|c|}{ Parent rock: pegmatite (north-facing slope) } \\
\hline \multirow[t]{5}{*}{2} & A & $0-9$ & 133.6 & 1.61 & 49.4 & 112.0 & 127.5 \\
\hline & BA & $9-40$ & 115.3 & 1.57 & 81.7 & 129.5 & 138.5 \\
\hline & Bw1 & $80-40$ & 117.8 & 1.71 & 78.2 & 142.5 & 145.0 \\
\hline & Bw2 & $80-110$ & 133.6 & 1.85 & 114.3 & 117.5 & 141.0 \\
\hline & $\mathrm{CB}$ & $110-130$ & 135.5 & 1.39 & 132.8 & 122.5 & 153.5 \\
\hline \multicolumn{8}{|c|}{ Parent rock: pegmatite (north-facing slope) } \\
\hline \multirow[t]{3}{*}{3} & A & $0-12$ & 50.3 & 0.38 & 37.5 & 121.0 & 5.5 \\
\hline & $\mathrm{Bw}$ & $12-27$ & 48.4 & 0.209 & 24.0 & 148.5 & 29.0 \\
\hline & $\mathrm{C}$ & $27-50$ & 52.5 & 0.126 & 15.0 & 147.0 & 15.0 \\
\hline \multicolumn{8}{|c|}{ Parent rock: pegmatite (south-facing slope) } \\
\hline \multirow[t]{3}{*}{4} & $\mathrm{~A}$ & $0-12$ & 45.2 & 0.254 & 39.0 & 95.5 & 15.9 \\
\hline & $\mathrm{Bw}$ & $12-22$ & 54.7 & 0.209 & 17.95 & 120.5 & 27.5 \\
\hline & $\mathrm{C}$ & $27-40$ & 47.8 & 0.153 & 12.40 & 117.5 & 33.5 \\
\hline \multicolumn{8}{|c|}{ Parent rock: dolerite (north-facing slope) } \\
\hline \multirow[t]{4}{*}{5} & A & $0-10$ & 57.8 & 1.35 & 54.3 & 12.2 & 178.6 \\
\hline & Bw1 & $10-45$ & 60.3 & 1.36 & 50.2 & 12.1 & 186.4 \\
\hline & Bw2 & $45-60$ & 67.2 & 1.31 & 58.6 & 13.9 & 233.2 \\
\hline & $\mathrm{CB}$ & $60-80$ & 70.7 & 1.27 & 60.0 & 15.5 & 255.4 \\
\hline \multicolumn{8}{|c|}{ Parent rock: dolerite (south-facing slope) } \\
\hline \multirow[t]{3}{*}{6} & A & $0-10$ & 102.1 & 1.35 & 105.8 & 32.5 & 148.3 \\
\hline & $\mathrm{Bw}$ & $10-60$ & 104.4 & 1.28 & 88.8 & 39.8 & 139.4 \\
\hline & $\mathrm{C}$ & $60-80$ & 86.5 & 1.01 & 95.8 & 54.0 & 108.9 \\
\hline
\end{tabular}

slope (pedon 3). For iron, such trend only observed in the northern slope. The fate of $\mathrm{Mn}, \mathrm{Zn}$, and $\mathrm{Fe}$ in the topsoil (pedons 3 and 4) may be related to a process named as the biological pump or nutrient uplift. Consistent with the hypothesis, deep-rooted trees often act as pumps, uptaking metal from subsoil horizons into their root systems, translocating it to their leaves, and re-entering it to the topsoil with litter fall and decomposition, causing much higher the metals levels in the surface (Rezapour 2013). In contrast with $\mathrm{Mn}$ and $\mathrm{Zn}$ pattern, $\mathrm{Cu}$ and $\mathrm{Ni}$ were depleted from the surface soil of pedons 3 and 4 which may be attributed to the process of acidic condition $(\mathrm{pH}<6$, Table 3 ) in the pedons because of trace metals are more solution in acidic environments (Kabata-Pendias and Mukherjee 2007). Iron, $\mathrm{Zn}, \mathrm{Cu}, \mathrm{Ni}$ were enriched in the Bw horizons of the pedons of 5 and 6 , developed on dolerite, mainly in the northern slope (Table 5). As discussed before, such enrichments can be explained by the interactions between several biogeochemical processes in the soils (i.e., humification and dissolution/leaching) as well as physical processes such as water fluxes (Acosta et al. 2011).

Table 6 The ratio of trace metal concentration in topsoil to that in the corresponding subsoil enrichment (RTE) in soils developed on three types of parent rocks

\begin{tabular}{|c|c|c|c|c|c|c|}
\hline \multirow[t]{2}{*}{ Trace metal } & \multicolumn{2}{|c|}{ Peridotite } & \multicolumn{2}{|c|}{ Pegmatite } & \multicolumn{2}{|c|}{ Dolerite } \\
\hline & $\mathrm{N}$ & $\mathrm{S}$ & $\mathrm{N}$ & $\mathrm{S}$ & $\mathrm{N}$ & $\mathrm{S}$ \\
\hline $\mathrm{Fe}\left(\mathrm{g} \mathrm{kg}^{-1}\right)$ & 0.818 & 0.99 & 10.04 & 0.827 & 0.897 & 0.907 \\
\hline $\operatorname{Mn}\left(\mathrm{g} \mathrm{kg}^{-1}\right)$ & 0.802 & 0.893 & 1.474 & 1.215 & 1.071 & 1.02 \\
\hline $\mathrm{Zn}\left(\mathrm{mg} \mathrm{kg}^{-1}\right)$ & 1.021 & 0.681 & 1.563 & 2.173 & 1.089 & 0.998 \\
\hline $\mathrm{Cu}\left(\mathrm{mg} \mathrm{kg}^{-1}\right)$ & 0.924 & 0.930 & 0.815 & 0.793 & 0.815 & 0.938 \\
\hline $\mathrm{Ni}\left(\mathrm{mg} \mathrm{kg}^{-1}\right)$ & 0.625 & 0.930 & 0.190 & 0.577 & 0.999 & 0.851 \\
\hline
\end{tabular}

$N$ northern slope, $S$ southern slope 
Overall, the values of $\mathrm{Fe}$, cu, and $\mathrm{Ni}$ were considerable lower in topsoil than in subsoil mainly in the northern slope, suggesting that mobilization and accumulation was occurred for the metals. On the contrary, the content of Mn and $\mathrm{Zn}$ was greater in topsoil than in subsoil, believing that the metals concentration in the topsoil was occurred for most of the studied soils particularly due to their strong affinities with the soil solid fraction or the recycling of metals by vegetation (Kabata-Pendias and Mukherjee 2007). The concentration of a element in topsoil divided by concentration of that element in the corresponding subsoil [(RTE) defined as a relative index of the mobility of metals] (Mapanda et al. 2005) was as following ranges (Table 6): Fe from 0.83 to $0.99, \mathrm{Mn}$ from 0.80 to $1.47, \mathrm{Zn}$ from 0.68 to $2.17, \mathrm{Cu}$ from 0.79 to 0.93 , and $\mathrm{Ni}$ from 0.19 to 0.85 . The mobility of metals, based on RTE values,

Table 7 Correlation coefficients $(r)$ between selected trace metals together and some soil properties

\begin{tabular}{|c|c|c|c|c|c|c|c|c|c|}
\hline & $\mathrm{Fe}$ & $\mathrm{Mn}$ & $\mathrm{Zn}$ & $\mathrm{Cu}$ & $\mathrm{Ni}$ & $\mathrm{OM}$ & Clay & CEC & $\mathrm{CCE}$ \\
\hline $\mathrm{Fe}$ & 1.00 & & & & & & & & \\
\hline $\mathrm{Mn}$ & $0.63 * *$ & 1.00 & & & & & & & \\
\hline $\mathrm{Zn}$ & $55.2 *$ & $0.71 * *$ & 1.00 & & & & & & \\
\hline $\mathrm{Cu}$ & $0.44 *$ & $0.45 *$ & $0.71 * *$ & 1.00 & & & & & \\
\hline $\mathrm{Ni}$ & $0.53 *$ & $0.52 *$ & 0.24 & 0.21 & 1.00 & & & & \\
\hline SOM & 0.21 & 0.18 & 0.15 & 0.23 & 0.17 & 1.00 & & & \\
\hline Clay & 0.51 & 0.20 & 0.15 & 0.40 & 0.11 & 0.34 & 1.00 & & \\
\hline CEC & $0.56 *$ & 0.33 & 0.28 & 0.25 & 0.21 & 0.14 & $0.9 * * *$ & 1.00 & \\
\hline $\mathrm{CCE}$ & -0.35 & $-0.61 * *$ & $-0.55 *$ & -0.31 & -0.26 & 0.07 & 0.23 & 0.02 & 1.00 \\
\hline
\end{tabular}

SOM soil organic matter, $C E C$ cation exchange capacity, $C C E$ calcium carbonate equivalent

$* P<0.05 ; * * P<0.01$; *** $P<0.001$

Table 8 Description of the geologic index $\left(I_{\text {geo }}\right)$ in soils developed on three types of parent rocks

\begin{tabular}{|c|c|c|c|c|c|c|}
\hline \multirow[t]{2}{*}{ Trace metal } & \multicolumn{3}{|c|}{ North-facing slope } & \multicolumn{3}{|c|}{ South-facing slope } \\
\hline & $I_{\text {geo }}$ value & $I_{\text {geo }}$ grade & Pollution Intensity & $I_{\text {geo }}$ value & $I_{\text {geo }}$ grade & Pollution Intensity \\
\hline \multicolumn{7}{|l|}{ Peridotite } \\
\hline $\mathrm{Fe}\left(\mathrm{g} \mathrm{kg}^{-1}\right)$ & -0.067 & 0 & Unpolluted & -0.065 & 0 & Unpolluted \\
\hline $\operatorname{Mn}\left(\mathrm{g} \mathrm{kg}^{-1}\right)$ & 0.011 & 1 & Unpolluted to Moderately polluted & -0.114 & 0 & Unpolluted \\
\hline $\mathrm{Zn}\left(\mathrm{mg} \mathrm{kg}^{-1}\right)$ & -0.221 & 0 & Unpolluted & -0.155 & 0 & Unpolluted \\
\hline $\mathrm{Cu}\left(\mathrm{mg} \mathrm{kg}^{-1}\right)$ & 0.274 & 1 & Unpolluted to Moderately polluted & 0.364 & 1 & Unpolluted to Moderately pollutec \\
\hline $\mathrm{Ni}\left(\mathrm{mg} \mathrm{kg}^{-1}\right)$ & 0.038 & 1 & Unpolluted to Moderately polluted & -0.256 & 0 & Unpolluted \\
\hline \multicolumn{7}{|l|}{ Pegmatite } \\
\hline $\mathrm{Fe}\left(\mathrm{g} \mathrm{kg}^{-1}\right)$ & 0.440 & 1 & Unpolluted to Moderately polluted & 0.430 & 1 & Unpolluted to Moderately pollutec \\
\hline $\operatorname{Mn}\left(\mathrm{g} \mathrm{kg}^{-1}\right)$ & -0.101 & 0 & Unpolluted & -0.140 & 0 & Unpolluted \\
\hline $\mathrm{Zn}\left(\mathrm{mg} \mathrm{kg}^{-1}\right)$ & -0.462 & 0 & Unpolluted & -0.484 & 0 & Unpolluted \\
\hline $\mathrm{Cu}\left(\mathrm{mg} \mathrm{kg}^{-1}\right)$ & 0.156 & 1 & Unpolluted to Moderately polluted & 0.058 & 1 & Unpolluted to Moderately pollutec \\
\hline $\mathrm{Ni}\left(\mathrm{mg} \mathrm{kg}^{-1}\right)$ & -0.079 & 0 & Unpolluted & 0.043 & 1 & Unpolluted to Moderately pollutec \\
\hline \multicolumn{7}{|l|}{ Dolerite } \\
\hline $\mathrm{Fe}\left(\mathrm{g} \mathrm{kg}^{-1}\right)$ & -0.157 & 0 & Unpolluted & -0.350 & 0 & Unpolluted \\
\hline $\operatorname{Mn}\left(\mathrm{g} \mathrm{kg}^{-1}\right)$ & -0.089 & 0 & Unpolluted & -0.055 & 0 & Unpolluted \\
\hline $\mathrm{Zn}\left(\mathrm{mg} \mathrm{kg}^{-1}\right)$ & -0.072 & 0 & Unpolluted & -0.328 & 0 & Unpolluted \\
\hline $\mathrm{Cu}\left(\mathrm{mg} \mathrm{kg}^{-1}\right)$ & -0.295 & 0 & Unpolluted & -0.804 & 0 & Unpolluted \\
\hline $\mathrm{Ni}\left(\mathrm{mg} \mathrm{kg}^{-1}\right)$ & -0.093 & 0 & Unpolluted & 0.117 & 1 & Unpolluted to Moderately pollutec \\
\hline
\end{tabular}


Table 9 Description of the CF and degree of contamination $\left(C_{\mathrm{d}}\right)$ in soils developed on three types of parent rocks

\begin{tabular}{lllllllll}
\hline Parent rock type & & $\mathrm{CF}$ & & & \multicolumn{3}{c}{$C_{\mathrm{d}}$} \\
\cline { 3 - 6 } & & $\mathrm{Fe}$ & $\mathrm{Mn}$ & $\mathrm{Zn}$ & $\mathrm{Cu}$ & $\mathrm{Ni}$ & \\
\hline Peridotite & North-facing slope & 1.285 & 1.538 & 0.901 & 2.819 & 1.638 & 8.181 \\
& South-facing slope & 1.288 & 1.154 & 1.03 & 3.465 & 0.826 & 7.763 & 1.553 \\
Pegmatite & North-facing slope & 4.129 & 1.189 & 0.518 & 2.150 & 1.250 & 9.236 & 1.847 \\
& South-facing slope & 4.038 & 1.087 & 0.493 & 1.716 & 1.656 & 8.99 & 1.798 \\
Dolerite & North-facing slope & 1.045 & 1.222 & 1.271 & 0.761 & 1.211 & 5.45 & 1.090 \\
& South-facing slope & 0.663 & 1.320 & 0.705 & 0.235 & 1.966 & 4.889 & 0.978 \\
\hline
\end{tabular}

Fig. 2 Histogram of the degree of contamination $\left(C_{\mathrm{d}}\right)$ for the soils developed on the different parent rocks. The horizontal lines are shown boundaries between very low to low degrees of contamination

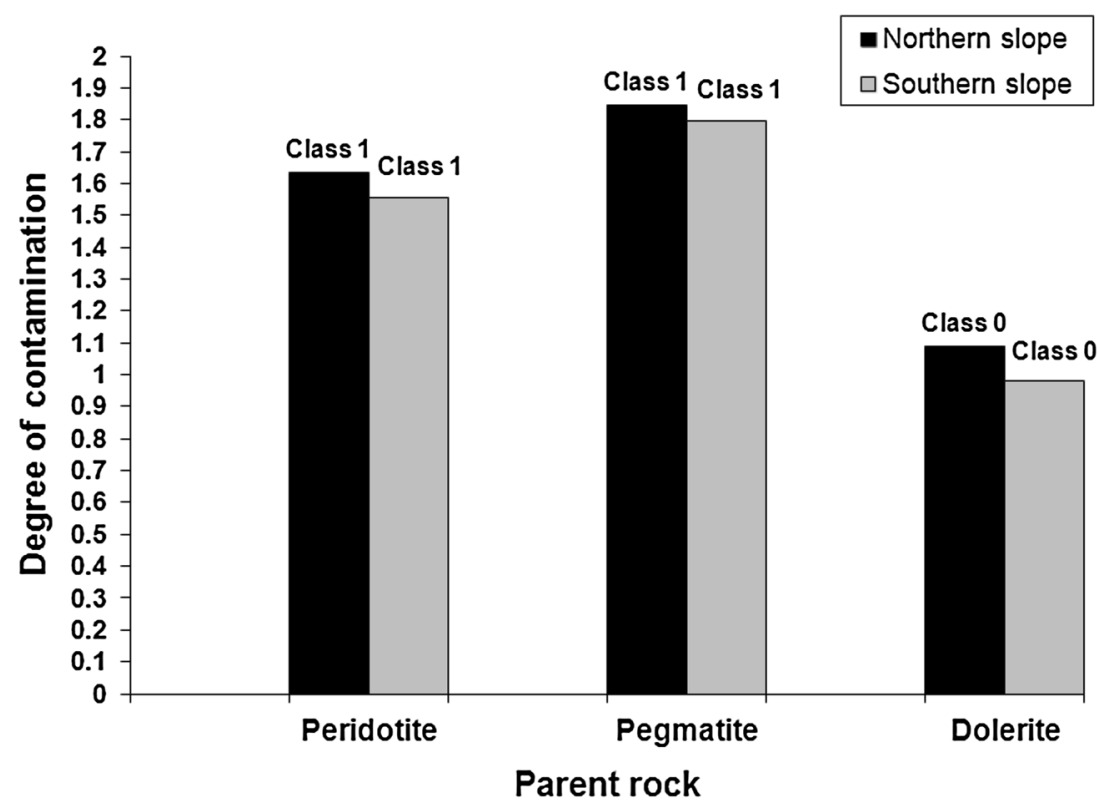

decreased in the sequence of $\mathrm{Ni}>\mathrm{Cu}>\mathrm{Fe}>\mathrm{Mn}>\mathrm{Zn}$. This pattern appeared both the two aspect agreement and disagreement with earlier reports (Camobreco et al. 1996; Haiyan and Stuanes 2003; Rezapour and Samadi 2011). There also found a greater Ni concentration in BC, CB, C horizons for all the examined pedons (Table 5) which may be interpreted to a much greater Ni downward removal rate compared to other metals.

Statistically, a significant correlation was found between Fe with Mn, Zn, and Ni (Table 7). Two main hypothesizes can be proposed to explain this observation: (1) Iron, presented in minerals with large surface area (such as ferrihydrite, hematite, and goethite), is an effective sorbent for $\mathrm{Mn}, \mathrm{Zn}, \mathrm{Cu}$, and Ni. Koons et al. (1980) mentioned that trace metals (e.g., $\mathrm{Co}$ and $\mathrm{Cr}$ ) were often associated with iron oxides minerals in the weathering of granite to saprolite. Bigham et al. (2002) and Acosta et al. (2011) reported that natural iron oxides have a high tendency for adsorption and transport of trace metals. (2) Genesis, transport, and accumulation of Fe was occurred in a similar pattern with $\mathrm{Mn}, \mathrm{Zn}$, and $\mathrm{Ni}$ which is in agreement to earlier observations by Zhang et al. (2002) and Xue-Song et al. (2006). Also, a significant correlation was recorded between $\mathrm{Mn}-\mathrm{Zn}(P \leq 0.01)$, Mn-Ni $(P \leq 0.05)$, and $\mathrm{Mn}-$ $\mathrm{Cu}(P \leq 0.05)$, suggesting similar behavior or common origin of these elements in the studied soils.

\section{Assessment of soil pollution scales}

Three indices of geologica index $\left(I_{\text {geo }}\right)$, degree of contamination $\left(C_{\mathrm{d}}\right)$, and PLI were assessed for estimating soil pollution. The $I_{\text {geo }}$ values of for $\mathrm{Fe}, \mathrm{Mn}, \mathrm{Zn}, \mathrm{Cu}$, and $\mathrm{Ni}$ 


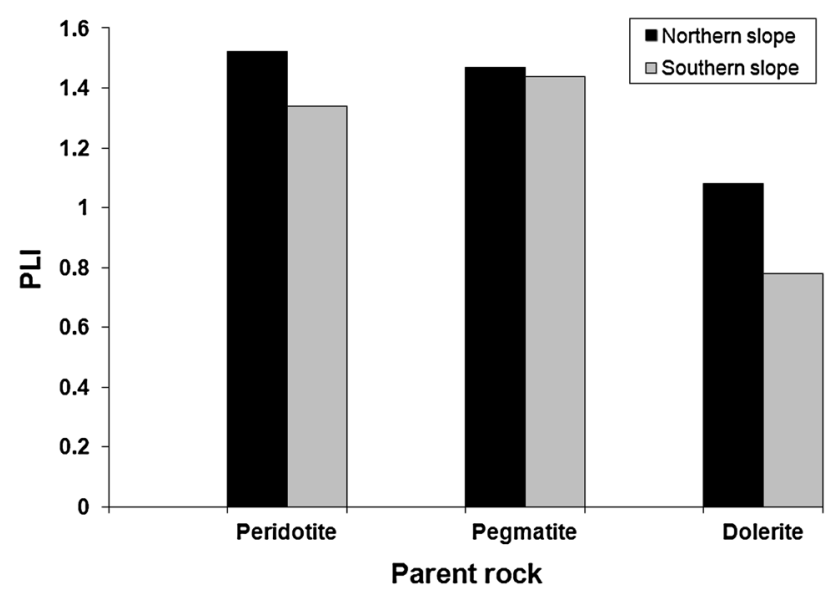

Fig. 3 Histogram of the PLI for the soils developed on the different parent rocks. The horizontal line is shown baseline levels

ranged from -0.35 to 0.44 , from -0.14 to 0.01 , from -0.48 to -0.07 , from -0.8 to -0.36 , and from -0.26 to -0.12 , respectively, showing unpolluted level $\left[I_{\text {geo }} \leq 0\right.$ (class 0)] and unpolluted to moderately polluted levels $\left[0<I_{\text {geo }}<1\right.$ (class 1)] (Table 8). Soils developed on the south-facing slope appear to be at least $I_{\text {geo }}$ values, whereas soils derived on the north-facing slope manifest higher $I_{\text {geo }}$ values for most of the examined metals which may be attribute to greater degree of chemical weathering on the north-facing soils. The negative $I_{\text {geo }}$ values found in the study can be considered as the result of relatively low levels of contamination for most of the metals and the background variability factor (1.5) in the $I_{\text {geo }}$ equation (Abrahim and Parker 2008).

The values of $C_{\mathrm{d}}$ for the five examined metals were in range of $0.078-1.85$ (Table 9) indicating very low (class 0 , $C_{\mathrm{d}}<1.5$ ) to low degree of contamination (class 1 , $\left.1.5<C_{\mathrm{d}}<1\right)$. The $C_{\mathrm{d}}$ was least $(0.98-1.1)$ for soils developed on dolerite, intermediate (1.5-1.64) for peridotite, and strong (1.8-1.85) for pegmatite. Indeed, the values of $C_{\mathrm{d}}$ show that 67 and $37 \%$ of the soils classified as low and very low of contamination, respectively (Fig. 2). For all the assessed pedons, the values of $C_{\mathrm{d}}$ were greater on the north-facing soils than those on the south-facing slope, manifesting that aspect have greatly influenced on weathering rate of trace metal-bearing rocks.
The values of PLI were found to be $>1$ for the pedons 1 , 2, 3, and 4 (Fig. 3). At this level, the soil metal concentration is above the soil background values and it could be appeared as the fate of trace metals [PLI $>1$ is indicative of soil pollution (Kalavrouziotis et al. 2013)]. In pedons 5 and 6 , on the contrary, PLI values were calculated to be $\leq 1$ suggesting that the soil metal concentration is equal (or less) to the soil background values. Like to the pattern of $I_{\text {geo }}$ and $C_{\mathrm{d}}$, the values of PLI were more in soils on the northern slope compared to soils on the southern slope, showing aspect most likely exerts an important control on soil pollution indices.

\section{Conclusion}

Soils developed on different parent rocks including peridotite, pegmatite, and dolerite reflected heterogeneous response to topography aspect and geopedological processes regarding to the total values of $\mathrm{Fe}, \mathrm{Mn}, \mathrm{Zn}, \mathrm{Cu}$, and $\mathrm{Ni}$. For instance, the concentration of the metals in the different soils, grouped by parent rocks, varied in the following orders: $\mathrm{Fe}, \mathrm{Mn}$, and $\mathrm{Ni}$ as peridotite $>$ dolerite $>$ pegmatite, $\mathrm{Zn}$ dolerite $>$ peridotite $>$ pegmatite and $\mathrm{Cu}$ as pegmatite $>$ peridotite $>$ dolerite. Two contrasting patterns of depletion and enrichment were observed in the profile distribution of the metals. We hypothesize that the depletion pattern of $\mathrm{Fe}, \mathrm{Cu}$, and $\mathrm{Ni}$ in the surface horizons is mainly controlled by dissolution/leaching and redistribution processes, whereas the enrichment pattern of $\mathrm{Zn}$ and $\mathrm{Cu}$ in the topsoil is influenced by the soil solid fraction (such as clay and organic matter) and biological cycling. Comparing to the south-facing slope, the contents of $\mathrm{Fe}$, $\mathrm{Mn}, \mathrm{Zn}, \mathrm{Cu}$, and $\mathrm{Ni}$ along with the examined pollution indices $\left(I_{\text {geo }}, \mathrm{Cd}, \mathrm{PLI}\right)$ were higher in the soils on the northfacing slope for most of the investigated pedons.

Acknowledgments The authors wish to extend their gratitude to all who supported this work.

\section{References}

Abrahim GMS, Parker RJ (2008) Assessment of heavy metal enrichment factors and the degree of contamination in marine sediments from Tamaki Estuary, Auckland, New Zealand. Environ Monit Assess 136:227-238 
Acosta JA, Martínez-Martínez S, Faz A, Arocen J (2011) Accumulations of major and trace elements in particle size fractions of soils on eight different parent materials. Geoderma $161: 30-42$

Alloway BJ (1995) The origins of heavy metals in soils. In: Alloway BJ (ed) Heavy metals in soils. Wiley, New York, pp 29-39

Aussendorf M, Suttner T, Martin W (2000) The problematic associated with the use of background levels in connection with the German Soil Protection Act. Umweltwiss SchaddstoffForschung 12:279-283

Baker DE, Amacher MC (1982) Nickel, copper, zinc and cadmium. In: Page AL et al (eds) Methods of soil analysis part 2. American Society of Agronomy, Madison, pp 323-336

Bech J, Tobias FJ, Roca N, Rustullet J (1998) Trace elementals in some Mediterranean Red Soils from the NE of Spain. Agrochimica XL(1-2):26-40

Bigham JM, Fitzpatrick RW, Schulze DG (2002) Iron oxides. In: Dixon JB, Schulze DG (eds) Soil mineralogy with environmental applications. American Society of Agronomy, Madison, pp 323-367

Braun JJ, Pagel M, Herbilln A, Rosin CH (1993) Mobilization and redistribution of REEs and thorium in a syenitic lateritic profile: a mass balance study. Geochim Cosmochim Acta 18:4419-4434

Bulmer CE, Lavkulich LM (1994) Pedogneic and geochemical processes of ultramafic rocks along a climate gradient in southwestern British Columbia. Can J Soil Sci 74:165-177

Cabrera F, Clemente L, Diaz Barrientos E, Lopez R, Murillo JM (1999) Heavy metal pollution of soils affected by the Guadiamar toxic flood. Sci Total Environ 242:117-129

Camobreco VJ, Richards BK, Steenhuis TS, Peverly JH, McBride MB (1996) Movement of heavy metals through undisturbed and homogenized soil columns. Soil Sci 161:740-750

Chapman HD (1965) Cation exchange capacity. In: Black CA (ed) Methods of soil analysis, part 2. American Society of Agronomy, Madison, pp 891-900

Colaka F, Atar N, Yazıcioglu D, Olgun A (2011) Biosorption of lead from aqueous solutions by Bacillus strains possessing heavymetal resistance. Chem Eng J 173:422-428

Darvishzadeh SA (2002) Geology of Iran. Amirkabir, Tehran

Gee GW, Bauder JW (1986). Particle-size analysis. In Klute A (ed) Methods of soil analysis. Part 1. Physical and mineralogical methods, 2nd edn. Agronomy monograph no. 9, ASA-SSSA, Madison, pp 383-411

Gupta VK, Yola ML, Atar N, Üstündağ Z, Solak AS (2013) A novel sensitive $\mathrm{Cu}$ (II) and $\mathrm{Cd}(\mathrm{II})$ nanosensor platform: graphene oxide terminated p-aminophenyl modified glassy carbon surface. Electrochim Acta 112:541-548

Haiyan W, Stuanes AO (2003) Heavy metal pollution in air-watersoil-plant system of Zhuzhou city, Hunan Province. Water Air Soil Pollut 147:79-107

Kabata-Pendias A, Mukherjee AB (2007) Trace elements in soils and plants. Springer, Berlin

Kabla C, Szerszen L (2002) Profile distribution of lead, zinc, and copper in Dystric Cambisols developed from granite and gneiss of the Sudetes Mountains, Poland. Water Air Soil Pollut 138:307-317

Kalavrouziotis IK, Rezapour Salar, Koukoulakis PH (2013) Wastewater status in Greece and Iran. Fresenius Environ Bull 22:11-21

Khormali F, Ghergherechi Sh, Kehl M, Ayoubi Sh (2012) Soil formation in loess-derived soils along a subhumid to humid climate gradient, Northeastern Iran. Geoderma 179:113-122

Koons RD, Helmke PA, Jackson ML (1980) Association of trace elements with iron oxides during weathering. Proc Soil Sci Soc Am 44:155-159

Ma L, Jin L, Brantley SL (2011) How mineralogy and slope aspect affect REE release and fractionation during shale weathering in the Susquehanna/Shale Hills critical Zone observatory. Chem Geol 290:31-49

Mapanda F, Mangwayana EN, Nyamangara J, Giller KE (2005) The effect of long-term irrigation using wastewater on heavy metal contents of soils under vegetables in Harare, Zimbabwe. Agric Ecosyst Environ 107:151-165

Müller G (1969) Index of geoaccumulation in the sediments of the Rhine River. GeoJournal 2:108-118

Nael M, Khademi H, Jalalian A, Schulin R, Kalbasi M, Sotohian F (2009) Effect of geo-pedological conditions on the distribution and chemical speciation of selected trace elements in forest soils of western Alborz, Iran. Geoderma 152(157):170

Nagajyoti PC, Lee KD, Sreekanth TVM (2010) Heavy metals, occurrence and toxicity for plants: a review. Environ Chem Lett 8:199-216

Nelson RE (1982) Carbonate and gypsum. In: Page AL (ed) Methods of soil analysis. Part 2. American Society of Agronomy, Madison, pp 181-199

Nelson DW, Sommers LE (1982) Total carbon, organic carbon, and organic matter. In: Page AL (ed) Methods of soil analysis, part 2. American Society of Agronomy, Madison, pp 539-580

Olgun A, Atar N (2011) Removal of copper and cobalt from aqueous solution onto waste containing boron impurity. Chem Eng J. 167:140-147

Paulo C, Gomes-Mauricio PF, Fontes-Aderbal GS, de Eduardo SM, Andre RN (2005) Selectivity sequence and competitive adsorption of heavy metals by Brazilian Soils. Soil Sci Am J 69:353-361

Rezapour S (2013) Response of some soil attributes to different land use types in calcareous soils with Mediterranean type climate in north-west of Iran. Envion Earth Sci. doi:10.1007/s12665-0132625-3

Rezapour S, Samadi A (2011) Soil quality response to long-term wastewater irrigation in inceptisols from a semi-arid environment. Nutr Cycle Agroecosyst 91:269-280

Seaward MRD, Richardson DHS (1990) Atmospheric sources of metal pollution and effects on vegetation. In: Shaw AJ (ed) Heavy metal tolerance in plants evolutionary aspects. CRC Press, Boca Raton, pp 75-94

Sidari M, Ronzello G, Vecchio G, Muscolo A (2008) Influence of slope aspects on soil chemical and biochemical properties in a 
Pinus Iaricio forest ecosystem of Aspromonte (Southern Italy). Eur J Soil Bio 44:364-372

Soil Survey Staff (2010) Keys to soil taxonomy. United States Department of Agriculture, Natural Resources Conservation Service, Washington

Xue-Song W, Yong Q, Yong-Kang C (2006) Heavy meals in urban roadside soils, part 1: effect of particle size fractions on heavy metals partitioning. Environ Geol 50:1061-1066
Brady NC, Weil RR (1999) The nature and properties of soils. Prentice-Hall, Englewood Cliffs

Zhang XP, Deng W, Yang XM (2002) The background concentrations of 13 soil trace elements and their relationships to parent materials and vegetation in Xizang (Tibet), China. J Asian Earth Sci 21:167-174 